\title{
Gender and Crises in European Economic Governance: Is this Time Different?*
}

\author{
MUIREANN O'DWYER ID \\ University of St Andrews, St Andrews, Scotland
}

\begin{abstract}
There is now a significant literature engaging with questions around gender and economic governance in the European Union. This builds upon research that demonstrates the gendered nature of the economy, and the gendered impacts of policy interventions. This paper draws on that research to develop an account of the gendered nature of the EU's crisis response, moving from analysis of the response to the Global Financial Crisis to some prelimary discussions of the EU's economic response to the COVID-19 pandemic. The paper shows how at each stage policies generate gendered consequences, and are built upon gendered assumptions about society and the economy. This paper therefore connects the feminist literature on the European Economic Governance to debates on the COVID-19 response, using a focus on gender and gender equality to examine key continuities between the crisis fighting of the Global Financial crisis to the establishment of the Next Generation EU fund.
\end{abstract}

Keywords: European economic governance; feminist political economy; crisis; gender

\section{Introduction}

The Global Financial Crisis (GFC) and the COVID-19 Pandemic are very different crises, but they are certainly both gendered. A wealth of empirical work documented the gendered consequences of the GFC, with work focused on the European Union (EU) highlighting the gendered consequences of the austerity measures taken in response to the crisis (Elomaki, 2012; Bettio, 2013; Karamessini and Rubery, 2013; Bruff and Wöhl, 2016; Emejulu and Bassel, 2017). While the economic consequences of the pandemic, and associated policy responses, are still much fresher, there is already a growing empirical literature documenting the gendered distribution of adjustment (Cook and Grimshaw, 2020; Cullen and Murphy, 2021; Rubery and Tavora, 2021). The European Institute for Gender Equality reports that women and men experienced the initial decrease to employment in roughly similar measure, but that men were much more likely to regain employment in the following months, raising the prospect for a longer-term employment crisis for women (EIGE, 2021). In particular, according to the EIGE report migrant women seem to be experiencing these negative employment impacts the most. Beyond these broad employment numbers, women are disproportionately employed in some of

\footnotetext{
*I would like to thank the reviewers for their extremely helpful and insightful comments, as well as the editors of the special issue for their help and guidance. The paper benefitted from feedback at a EUROSEM workshop in January 2021 and the Dutch Political Science Association Annual Conference in June 2021. All errors remain my own. This article was supported in part by a Jean Monnet Network entitled "The Politics of the European Semester: EU Coordination and Domestic Political Institutions (EUROSEM)” Agreement number: 600110-EPP-1-2018-1-CA-EPPJMO-NETWORK (Grant agreement nr 2018-1359), with the support of the Erasmus+ programme of the European Union.

[Correction added on 29 January 2022, after first online publication: The copyright line was changed.]
} 
the hardest hit industries, such as hospitality and tourism, and also make up a large proportion of the 'key workers' who have been continuing to work outside of home during the pandemic. In addition, emerging research has pointed to how the shift to home working has entrenched or even furthered gender inequalities (Javorcik, 2021). This article takes this similarity - the entrenchment or generation of gendered inequalities - as an impetus to explore how feminist analysis of the experience of the GFC in the EU can help us to understand the current crisis. This is not to make any larger claims about the similarity of the two moments - indeed, the continuation of this gendered nature is particularly interesting precisely because of the differences between them.

One other important similarity to note is the emphasis on oversight and recommendation. The post-crisis governance framework of the European Semester required member states to submit budget plans, and to engage with a yearly cycle of recommendation and oversight (Verdun and Zeitlin, 2018). In response to the pandemic, and connected to its overall budget, the EU established the 'Next Generation EU' (NextGenEU) fund to support member states. Within this, the Recovery and Resilience Facility governs the issuance of grants and loans to the member states, to be spent in line with National Action Plans (NAPs) that each member state submits to the Commission for approval. So while much of the process of the European Semester has been suspended due to the pandemic, the governing logic of oversight and recommendation remains (Fabbrini, 2022; Vanhercke and Verdun, 2022).

While the rest of the paper works through an overarching timeline of crisis and crisis response to identify the key lessons to be drawn from feminist analysis, I want to highlight two key findings of the broader academic literature on economic crisis - that crises are gendered, and that crises are moments of intense legitimacy work. That economic crises are gendered may be obvious to anyone who has experienced one, however, as I discuss below, it is not guaranteed that policy makers will take account of this fact. Work from feminist economics and feminist political economy has shown how existing gender equalities and existing gender norms within societies shapes the experience of economic shocks and common policy responses. In particular, Diane Elson's work on a range of economic crises in Latin America, Asia, and, recently, Europe has highlighted how male biases within policy making both serve to obscure the gendered impacts of economic shocks, and lead to policies which exacerbate them (Elson and Cagatay, 2000; Elson, 2013, 2010, 1994, 1991). I will discuss this gendered nature of economic crisis more in the sections which follow, however it is an important starting point for the entire paper.

The second such starting point is the connection between crises and legitimacy. For understandable reasons, economic crises raise questions about the efficacy, and therefore the legitimacy, of economic policy makers. Moreover, crisis response often involves the deployment of new or less common policy measures, again raising the need for legitimacy. In the context of the two crises which this paper focuses on, it's important also to note that the EU as a whole has been going through processes of legitimation, to greater or lesser success, for many decades (Schmidt, 2013; McNamara, 2015a, 2015b; Crum and Merlo, 2020). Feminist analysis adds to this point the finding that legitimacy is deeply intwined with gender - for example the austerity policies deployed in response to the financial crisis were legitimated through gendered discourses (O’Dwyer, 2018). In this paper, this connection between legitimacy and gender will be discussed at various points, as it connects to many of the key lessons being highlighted. In particular, there will be an 
emphasis on 'output legitimacy' rather than 'input legitimacy'. This distinction, articulated by Sharpf and others (Scharpf, 1999, 1997; Jones, 2009; Schmidt, 2013), helps to capture the broadness of legitimacy. While the EU can be often said to be lacking in input legitimacy due to weak or absent democratic oversight, it is the issue of output legitimacy that this paper will primarily engage with. Output legitimacy is often understood in terms of the overall benefits of a particular policy - the more beneficial, the more legitimate. While this is an important aspect, it is not the whole story, and indeed such a formulation raises additional questions. How is benefit to be defined and measured? And, just as importantly, who decides whether a policy is beneficial? This means that the process of output legitimacy is inherently a discursive one, involving the construction and maintenance of benchmarks (Pansardi and Battegazzorre, 2018). This is why particular constituencies were so important to early articulations of output legitimacy, such as trade unions, business groups, and other influential economic actors (Scharpf, 1999). Moreover, this then leads us to look at the gendered nature of these groups, and of the discursive processes through which actors both seek and bestow legitimacy (O'Dwyer, 2019). The importance of such discursive processes is highlighted by the developing literature that examines different policy actors communications, often with an explicit emphasis on the role such communications play in claims to legitimacy (Rosamond, 2014; Schmidt, 2014; Braun, 2016; Pansardi and Battegazzorre, 2018; Moschella et al., 2020; Vesan and Pansardi, 2021).

The rest of the paper is arranged as follows. I begin by looking at how crises are conceptualised and constructed, in particular through the process of framing. I then explore the policy processes of crises, before moving to examine the consequences of crises. In each of these sections I primarily focus on the experience of the GFC in the EU, drawing out key lessons from the feminist literature before turning to some initial discussion of the current moment. This structure maps onto the temporal process of crisis, though appreciating that of course such things are never so clearly delineated in reality.

\section{The Construction of Crises}

The first lesson to be drawn from feminist analysis of the GFC is that the framing shapes policy responses. To be sure, this is not an insight that is unique to feminist analysis (Daviter, 2007; Laffan, 2014; Pottier and Delette, 2019). Frames structure potential policy responses - they set the register in which discussion and debate take place. Crises do offer opportunities for contestation over such frames, further highlighting their importance. In fact, a decade on from the GFC, there has been a lot of reflection on how the sequence of events, with Greece being the first member state to come under extreme pressure, created a framework for response that closed off alternative avenues, and may have led to the subdued, or even in some cases non-existent, recovery (Buti, 2020).

Critical framework analysis formed the basis of a large body of literature on gender mainstreaming in the EU (Lombardo and Meier, 2006; Lombardo et al., 2009). It is an approach that seeks to explore how meanings, of gender or other concepts, are utilised in the policy process. By seeing how policy discussion is framed, this literature identified the variation in understandings of gender, and of the problem of gender inequality, as a primary reason for the failure of gender mainstreaming (Verloo and Lombardo, 2007; Cavaghan, 2017). Thus, it is clear that the meaning of key concepts - such as gender, 
or crisis - is an important site of analysis at the beginning of the policy process. Given how much extra-ordinary policy was enabled precisely because of the context of crisis, it is extremely important to appreciate the political nature of what counts as crisis. Long-standing economic hardships are rarely framed in crisis terms, meaning that similar levels of poverty, unemployment, or precarity treated as a crisis in one moment, may be treated as 'normal' in another. This has significant gendered and racialized consequences (Strolovitch, 2013; Emejulu and Bassel, 2017), building on gendered and racialized expectations of what is 'normal'. Moreover, even that economic hardship that developed in the wake of the crisis, or as a result of the austerity based responses to the crisis, often did not get incorporated into the crisis frame. This had significant implications for the process of normalizing the new economic governance mechanisms, such as the European Semester (Cavaghan and O'Dwyer, 2018), in that when attention turned to recovery and embedding the new governance mechanisms these consequences for inequality were not factored in. Moreover, the treatment in much of the academic literature of the past decade as one of particularly intense crisis further invisibilizes the lived experiences of vulnerable and already suffering people, reflecting a broader narrowness in the conception of crisis in this literature (MacRae et al., 2021).

The above means that the understanding of the current crisis - and the frame that accompanies that understanding - will be crucial in shaping the politics of the EU's recovery package, including the NextGenEU funding. Frames can be by looking at the policy solutions adopted. This is because frames shape policy responses, and so it can be possible to 'read back' to the frame from the responses. Approaching a frame analysis of the current crisis in this way leads to some worrying initial conclusions. At both the member state level (Rubery and Tavora, 2021) and EU level (Klatzer and Rinaldi, 2020) the policy responses show limited signs of engagement with concerns of gender equality, or the EU's new Gender Action Plan (Rubery and Tavora, 2021).

For example, early discussions around the recovery funds prioritized male forms of employment, and male-dominated industries (such as transport and agriculture), in spite of the fact that female-dominated forms of employment (highly flexible or part time) and female-dominated industries (tourism and hospitality) have been the hardest hit by the pandemic and lockdowns (Cook and Grimshaw, 2020; Klatzer and Rinaldi, 2020). It may be suggested that the emphasis on transport and agriculture is due to the prioritization of an environmental transition, connected to the EU's Green Deal. This is clearly an important factor in a lot of the recovery debates, however it is also worth pointing out that the Green Deal, and policies for an environmental transition have also been subject to feminist analysis, and calls for gender mainstreaming in this area point to the crucial role for industries such as care and tourism in any transition (Allwood, 2020, 2017). So, while it may be that environmental concerns are seen as central to the recovery, environmental policies themselves are gendered, and should also be subject to gender mainstreaming.

Part of the recovery package involves funding national spending, outlined by the member states in NAPs submitted to the European Commission. This process builds on the governance mechanism of the European Semester, meaning that there is a strong potential of a continuation of the gendered dynamics of that system (Cavaghan and O'Dwyer, 2018; O'Dwyer, 2018; Cavaghan and Elomäki, 2021). At the time of writing, NAPs are in the process of being submitted and approved (or not), and so it is not possible to offer a full 
analysis here. However, it is worth noting that despite a requirement in the Recovery and Resilience Facility Regulation ${ }^{1}$ to outline the contribution to gender equality of the proposals, some NAPs, the member states have interpreted this in a variety of ways, with several having no explicit allocations to gender equality projects. This variation in the meaning and priority given to gender equality looks quite like a continuation of many of the challenges of gender mainstreaming (Guerrina, 2020). Importantly, it also indicates the potential for crises to be read as gender neutral, despite the empirical evidence to the contrary. Such a reading is a key factor in driving the gendered nature of the policy process, which I turn to in the next section.

\section{The Policy Processes of Crises}

There are many ways in which policy making may be gendered. In this section, I outline the second lesson - that the legitimation processes of policy-making are gendered. This line of analysis begins with Elson (1994) who identifies that the gendered nature of the institutions and networks and spaces of economic policy is what makes gendered policy and gendered outcomes so inevitable. This starting point is particularly useful because it allows us to see a policy process as gendered even when - especially when - it is silent on gender. Rather than seeing silence around gender equality and related concerns in a policy as a sign of a policy's 'gender neutrality', instead we can see that same silence as evidence of the perpetuation of the gendered bias stemming from the male dominance of decision making. This means that work that identifies such male dominance in decision making is an essential first step in exploring the broader role played by gender in a policy area (Schuberth and Young, 2011; O'Dwyer, 2019).

For the GFC, analysis of both the EU (O'Dwyer, 2019) and the broader global economic governance system (Schuberth and Young, 2011) demonstrated a strong gender imbalance, in particular at the higher levels of decision making. In particular, key advisory groups or boards within the EU, including the ECB Governing body and multiple committees established to examine the cause of the GFC and make recommendations for reforms were often homogeneously male, or featured only one woman among their membership (O'Dwyer, 2019). This matters in particular as the ideas and documents established by such groups shape policy making throughout other levels (Cavaghan and Elomäki, 2021). Since the early years following the GFC, this issue of the under-representation of women in European economic policy making has become much more salient, in particular in the European Parliament, where attempts have been made to increase the number of women nominated to such roles (Begg, 2020).

Partly as a result of this increased salience of gender equality in decision making, the decision making spaces of 2020 and 2021 look quite different, from a gender perspective, than those that faced the GFC. At the highest levels, the Presidents of both the European Commission and the European Central Bank are now women, and both have played a significant role in the development of economic policy responses to the pandemic. There is still some asymmetry in decision making, however. For example, within the Commission key Directorate-Generals remain male-dominated, especially at the higher levels (Klatzer and Rinaldi, 2020). Similarly, while the ECB now has a female President in Christine 
Lagarde, she is one of only two female members of the governing council. ${ }^{2}$ However, the gendered nature of policy making is not limited to questions of representation - gender plays important roles in the legitimation processes of economic policy, regardless of the increased presence of women in positions of power.

Questions of legitimacy in the context of the EU vary greatly across time and policy areas. (Lord and Magnette, 2004; Follesdal, 2006), and they clearly matter for socio-economic governance (Csehi and Schulz, 2022) The method of decision making, whether following the community method, intergovernmental bargaining or some new hybrid system, impacts on how the question of legitimacy must be addressed. As indicated in the introduction, I follow Scharpf $(2014,1999)$ in his distinction between input and output legitimacy, focusing on how output legitimacy is generated in the field of contemporary economic governance. Input legitimacy is clearly often lacking in EU policymaking, in particular when non-majoritarian institutions such as the European Central Bank or the European Commission are empowered. It is this lack of input that has driven much of the criticism of the EU as having a 'democratic deficit', and has led to calls for increased roles for national parliaments, for example (Schout et al., 2016). Input legitimacy is particularly lacking in Europe's new economic governance regime, as both the European Parliament and national parliaments are side-lined (Collignon and Diessner, 2016; Dinan, 2016), whilst the technocratic side of the EU is empowered, through the Commission, the European Central Bank and the committees of the Council (Scharpf, 2014; Dinan, 2016; Seikel, 2016). These criticisms are not new but were justifiably increased since the crisis.

In analysing and evaluating legitimacy and European Economic Governance, then, output legitimacy is key. A decision has output legitimacy when it is, overall, beneficial - and crucially, when it is judged to be beneficial by key constituencies. For example, non-majoritarian institutions such as central banks are legitimized by their output of price stability: the argument goes that by being removed from political control, they can better serve the economic interest of the country, and so central banks exert considerable energy in communicating their success in achieving price stability and other goals connected to output legitimacy (Braun, 2016; Lokdam, 2020).

As Rosamond notes, "the project of economic integration cannot be accomplished without intensive activism on behalf of the generation of mass loyalties to "Europe" (Rosamond, 2002, p. 160). This requires a construction of an idea of 'Europe' and a 'European Economy' (Rosamond, 2002), which has in practice ignored the gendered nature of the actual economy (O'Dwyer, 2020). Legitimacy for economic policy making requires both the construction of the subject of such policy - the European economy - as well as a discursive justification of the policies undertaken. Such a justification operates within global systems of economic expertise (Fourcade, 2006), which prioritize a formalized and mathematical vernacular. Entry to, and success within this system requires an ability to interact with this language, as well as the performance of certain attributes of expertise, including race, gender, qualifications, and linguistic abilities (Schuberth and Young, 2011). This means that the male dominance of decision making spaces discussed at the start of this section actually plays a role in the legitimation process - within the 
transnational economic networks that are similarly male-dominated, male-ness itself can come to confer authority (Sanday, 1981; Acker, 1990).

Moreover, in seeking legitimacy through communication with networks that are often silent on gender concerns, it makes sense that perpetuating a similar gendered silence would enhance claims to output legitimacy. This could be seen in the legitimizing discourses around the austerity policies enacted in response to the GFC, where key architects of these policies justified and defended them against many criticisms (Buti and Carnot, 2013), but did not engage with any of the many feminist critiques. Even when accepting some flaws with the approach, the accounts given by such actors give no impression of appreciating the gendered consequences of that approach (Buti, 2020).

The way in which gendered silences can serve to legitimate economic policy has been well documented by feminist political economy, in particular through Bakker's work on the concept of the 'strategic silence' (Bakker, 1994). This idea helps to clarify how silence on questions of gender are not simply incidental, but in fact serve a purpose in generating both legitimacy and coherence for economic policy, as observed in the research on the austerity policies of the EU (O'Dwyer, 2018). Put bluntly, it is difficult to imagine a defence of such policies that acknowledged the, often extreme, gendered consequences of such policies that would successfully justify such an approach. This is one reason why both gender mainstreaming and other approaches such as gender budgeting hold such transformative potential without requiring any specific policies - simply the act of requiring policy makers to engage with, and acknowledge, the gendered consequences of their decisions creates pressure to adjust them in ways more conducive to gender equality and so, in the alternative, policy processes that are silent on gender avoid such pressures.

The politics of generating and maintaining legitimacy in the context of the COVID-19 pandemic may seem initially quite different to those faced by policy makers in the GFC. The constituencies at play in the generation of output legitimacy are much broader, reflecting the differences in both the scale and nature of the crisis. While in the previous crisis, the experience of economic crisis was much more concentrated in some member states, in this instance all member states faced lockdowns and the resultant economic damage, though the varying economic strength of the member states still created a variated experience. However, it is in the longer term that the lessons around legitimacy may become especially salient. As debates begin to develop over the recovery funds, and questions around a return to austerity begin to emerge, it is highly likely that a similar politics of legitimacy will return. What will be interesting to explore is whether the changes in the representative make-up of decision makers plays a role in this.

The extreme side-lining of gender equality concerns and gendered analysis that was observable in the early stages of crisis fighting in 2007-10 does not seem to have been repeated in the development of an economic policy response to the pandemic. This is an important initial observation, as it shows the potential that there has been some policy learning, and that perhaps the feminist research discussed earlier has had some impact. This reflects a change in the broader academic and policy debate, where there is a much greater engagement with issues of gender and gender equality than a decade ago. It may be that the very different nature of the economic shock that has resulted from the pandemic made such silencing impossible. While most recessions, including that in the 2010s, often cause higher unemployment spikes in male-dominated industries, this was not the case with the pandemic (Rubery and Tavora, 2021). Instead, the disproportionate 
impact on the female-dominated industries of tourism and hospitality has meant that women face a greater initial risk to their employment. Moreover, the increase in lower-hours work also creates potential gendered outcomes (Klatzer and Rinaldi, 2020). This is not to say, of course, that the GFC did not have significant gendered implications, with a disproportionate impact on women - as outlined above, it very clearly did. However, there seemed to a much greater visibility of this impact in the current crisis (Rubery and Tavora, 2021), though it remains to be seen whether this translates into the policies of the recovery.

Worryingly, it seems that, so far, the appreciation of the gendered nature of the crisis has not resulted in a full adoption of gender mainstreaming in the development of the economic recovery package. Early debates around the funding package as part of NextGenEU did not take the gendered nature of the labour market shocks into account. In an early assessment of the emerging programme, Klatzer and Rinaldi found that all aspects of the programme could be classified as 'gender-equality jeopardizing' (Klatzer and Rinaldi, 2020). In particular, the focus of the early documents and discussions around the spending plans was on particular, and male-dominated, industries such as construction, agriculture, and transport - highlighting the limited evaluation of the programme from a gender equality perspective, and also a poor understanding of the gendered nature of the economy. Through the intervention of the European Parliament, the regulation governing the NAPs and the recovery funds included a requirement to take account of the gendered aspects of both the pandemic and future spending plans (Elomaki and Kantola, 2021). Despite this, there is quite a variety in the level and type of gender analysis within the submitted NAPs. Clearly, some lessons remain to be learned, and despite an increase in the level of rhetoric around gender equality, gender mainstreaming has not been fully embedded in the development of the recovery plan. This is particularly concerning given that, through the reforms of 2020, the EU's economic governance system has potentially been transformed from a regulatory system to a much more explicitly redistributive one (Ladi and Tsarouhas, 2020).

\section{The Consequences of Crises}

The third and final lesson I will discuss concerns the need for - and the challenges to gender mainstreaming. Gender mainstreaming was supposed to bring gender sensitive analysis into all policy making processes at the EU level (Pollack and Hafner-Burton, 2000; Woodward, 2012; Jacquot, 2015a; Guerrina, 2020). The underpinning idea of gender mainstreaming is that all policies and policy areas have potential implications for gender equality and inequality, and so all policy processes should incorporate assessment and discussion of gender. It was adopted in the EU as a result of significant activism both within and outside of the EU institutions and was widely welcomed by feminist scholars as an opportunity to transform policy making (Lombardo and Meier, 2006; Hubert and Stratigaki, 2016; Guerrina, 2020). However, more than 20 years after its adoption, there is a broad consensus that sees its success as variable, at best (Jacquot, 2015a; Hubert and Stratigaki, 2016; Guerrina, 2020). It has become clear that it 'requires political will and commitment to be effective' (Guerrina, 2020, p. 137). This has meant that gender mainstreaming was only applied in the policy areas where actors were enthusiastic about the project, leaving several sectors relatively untouched by this supposedly trans-policy 
approach. Indeed, this reliance on political will has also made gender mainstreaming vulnerable to what has been described in other contexts as the 'duty to yield' (Skjeie, 2006), meaning that in times of crisis, concerns with gender equality lack priority, and gender mainstreaming gets side-lined.

Moreover, gender mainstreaming was at the mercy of differing interpretations of its role and purpose, and differing understandings of the meanings of gender and gender equality (Lombardo and Meier, 2008, 2006; Jenichen et al., 2018). Both of these findings point to the importance of actors within the adoption of gender mainstreaming, reflecting feminist analysis that pointed to the need for actors at various key points in the policy process to ensure the adoption of gender equality measures (Woodward, 2004). This means that analysis of the success or otherwise of gender mainstreaming needs to take account of the broad remit of the policy making process, including questions of representation and conceptual understandings.

The limitations of gender mainstream were clearly observed in the case in the responses to the GFC (Guerrina, 2017; Cavaghan and O'Dwyer, 2018; O'Dwyer, 2020). One of the first findings of feminist analysis of the various responses to the crisis, at the EU level, was that of a silence on questions of gender (O'Dwyer, 2020, 2018). This was in spite of the gendered nature of different phases of the crisis, with male-dominated industries hit hardest in the earlier stages, and female-dominated public sector jobs more at risk in later stages. Indeed, as discussed in the first section, there was significant empirical work done that demonstrated the starting insight of gender mainstreaming, that all policies can have gendered impacts (Elomaki, 2012; Bettio, 2013). However, despite this evidence, and despite that fact that some of the research was even being done by or on behalf of EU institutions or agencies, it did not seem to shape policy making within the field of economic governance. These two findings - of gendered impacts and gendered silences - are linked. As Diane Elson observed, bias in economic policy does not need to be explicit. In fact, bias through omission can be a key mechanism through which economic policy can generate biased policy that increases inequalities (Elson, 1991; O'Dwyer, 2018). Such an absence ignores the ways in which the actual economy itself is 'gendered via the social norms and networks which are functional to the smooth operation of those institutions'(Elson, 1994, p. 39).

Overall, the years immediately following the crisis have been described as a period of 'dismantling' when it comes to gender equality (Jacquot, 2015b, p. 173). This is not to claim that the financial crisis and related responses created a qualitative change in gender equality policies, but rather that austerity measures, combined with a narrowing of policy focus in moments of 'crisis fighting' intensified the reductions of resources and attention committed to gender equality, at both the EU and member state level. This highlights not only the limits of gender mainstreaming commitments to withstand crisis conditions, but also shows how crisis can exacerbate or accelerate worrying trends around gender equality, something clearly possible in the current crisis moment. This creates a wariness amongst feminist scholarship for seeing crises as moments of opportunity, given previous crises have been characterised by the entrenchment or even extension of inequalities (MacRae et al., 2021).

Over time, the governance architecture that emerged from the crisis, in particular the European Semester, did begin to incorporate some appreciation of the gendered nature of the economy, though this was primarily through a narrow understanding that 
emphasised the role of gender equality for economic growth (Elomäki, 2015; Cavaghan and O'Dwyer, 2018). Again, meaning was at the core of the problems facing the inclusion of gender concerns. In particular, gender equality seemed to be used in an instrumental sense, building upon earlier uses of 'business case feminism' within the EU (Elomäki, 2015). Additional research at the member state level found similar results, with a particular understanding of gender equality as equivalent to (and limited to) labour force activation leading to the co-option of gender equality language in the pursuit of labour market deregulation. This has been identified by work on Italy (Chieregato, 2021), Ireland (Cullen and Murphy, 2017) and Finland (Elomäki, 2019), among others.

A key contribution of feminist political economy has been to bring analysis of the private or domestic sphere into economic debates (Sassoon, 2018). This has been done through a focus on the household as a site of economic activity, inequality and normative contestation and construction (Elson, 1998; Cappellini et al., 2014; Bruff and Wöhl, 2016; Montgomerie, 2016). Analysis of the economics of the household, that is, the economics of care work and social reproduction more broadly, highlights the arbitrary nature of conceptualising the economy as limited to the realm of money - of paid work, finance, trade and government tax and spending. The study of social reproduction, a sub-field of feminist political economy, examines the role of reproductive work in the wider economy (Bakker, 2007, 2003; Roberts, 2013; Cavaghan and Elomäki, 2021; Stevano et al., 2021). This reproductive work concerns all that is required to reproduce a workforce. This ranges from the care and raising of children to the domestic labour required to support a work force and to the communal care work done through family networks or in neighbourhoods. This work is often, though not necessarily, unpaid. However, despite a large body of research by feminist political economists, and despite some success in encouraging the adoption of gender budgeting processes that would include analysis of reproductive work in national and international economic analysis (Elson, 2004; Çağlar, 2010; Addabbo et al., 2018), often this work is obscured or ignored in policy making.

Within European Economic Governance, this division of economics away from other policy areas has been a key focus of feminist critique (Bruff and Wöhl, 2016; Cavaghan and O'Dwyer, 2018; O'Dwyer, 2020). More recently, debates over the relationship between social policy and economic policy have developed in analysis of the European semester (Verdun and Zeitlin, 2018; Copeland and Daly, 2018, 2015; Zeitlin and Vanhercke, 2018; Jordan et al., 2020). On one side, scholars argue that the post-crisis governance framework, in particular the European Semester, prioritized economic goals at the expense of social priorities (Copeland and Daly, 2018; Dawson, 2018; Jordan et al., 2020). On the other side, scholars have noted a trend of increasing attention within the Semester to social policies, reflective of a gradual 'socialization' of the Semester (Zeitlin and Vanhercke, 2018; Vesan etal., 2021). Miró argues that this trend was reflected in the decision to suspend Semester rules in response to the pandemic, completing a process of increased 'flexibilization' of fiscal governance (Miró, 2020). This debate reflects differing conceptualizations of the Semester as a governance tool, meaning that for many on the 'anti-socialization' side of the argument, an increase in social recommendations may actually reflect the 'economization' of social policy. In addition, there is something of a temporal mismatch in this debate, with much of the arguments for 
'socialization' emphasizing the gradual nature of the process, and the potential for the full outcome of such a process to emerge in later rounds of the Semester process.

This debate can look somewhat different when a feminist perspective is taken (Cavaghan and O'Dwyer, 2018; Cavaghan and Elomäki, 2021). Feminist approaches reject the binary between social and economic, not only for the policy hierarchy it can create. When one looks at the changes to gender equality within the EU, it is clear that economic policy is transforming this supposedly social policy. Moreover, it is the interaction between social and economic policies that constitute the various gender regimes of states and organizations (Shire and Walby, 2020; Walby, 2020; MacRae et al., 2021). From the vantage point of the gender regime, economic and social policy are clearly co-constitutive, and so the question moves from one which explores the relative priority of either economic or social policy to one which is interested in how the interaction between the two shapes the policy outcomes that govern a particular society, While, from the perspective of gender equality, there has been a clear increase in the frequency of explicit references to gender in the European Semester documents, these are primarily concerned with reforms that improve gender equality in the interest of economic growth and greater competitiveness (Cavaghan and O'Dwyer, 2018). This means that analysis of economic policy needs to not only appreciate its interconnection with other policy areas, while also appreciating the inherent prioritization of aims within the range of recommendations and measurements that make up the semester.

The gender equality architecture of the EU has, in some ways been strengthened in more recent years, though perhaps not back to levels seen before that episode (Ahrens, 2018; Jacquot, 2020). The fact that the Recovery and Resilience Facility regulation does explicitly call for some gender sensitive analysis in the NAPs reflects this. The question to be asked in this crisis may perhaps be different. Rather than asking why there is no discussion of gender equality, we must now ask where and how the discussion is taking place. A key moment, from a feminist perspective, of the development of European economic governance was the shift of the Gender Equality Unit within the European Commission from the Directorate General for Employment to that of Justice (O’Dwyer, 2019; Guerrina, 2020; Jacquot, 2020, 2015b), reflecting a pervasive understanding of gender equality as a legal issue. That is, gender inequalities were to be understood as resulting from discriminations (illegal or legal), and so could be rectified by legal means. This builds upon an understanding of the role of the EU in relation to gender equality as ameliorative - aimed at correcting existing inequalities. This excludes an understanding of the role the EU may be playing in creating or enhancing such inequalities - and this exclusion is built on a framing of the economy as separate from social concerns, including gender equality.

In fact, the economic policies of the EU themselves serve to construct and maintain gendered hierarchies and inequalities (Cavaghan and O'Dwyer, 2018). That is, it is not simply that gender inequality concerns should be incorporated into economic policy, but that there needs to be an understanding that economic policy already is a gendered policy, albeit one that has often led to increases rather than decreases in inequality. This understanding underpins a key critique of the EU's structures, where gender equality (and, often, other important concerns) are excluded from economic policy making, and instead seen as a separate area of policy. This leads to disconnections and contradictions within the EU as a 'gender constitutive actor' (Cavaghan and O'Dwyer, 2018), with a 
Gender Equality Strategy that emphasises the economic underpinnings of inequality (Rubery and Tavora, 2021), but an economic policy system that ignores the gendered underpinnings of the economy.

\section{Conclusions}

In this article I have outlined the different ways in which the EU's economic policy making is gendered. In particular, I have emphasized how this gendered nature plays out at different stages of responding to economic crises. As discussed in the introduction, the current crisis resulting from the COVID-19 pandemic is, in very many ways, different to that which resulted from the GFC. Despite this, there are some similarities in the policy responses to both crisis. Moreover, the lessons that can be taken from feminist analysis of the GFC have clear applications in analysis of the current crisis, as I have shown within each section. I have shown, firstly, the importance of framing in constructing crises. The frames which are used shape the policy process which follows, raising the second lesson this paper highlighted - that the legitimation of policy-making is a gendered process. Finally, I explored the gendered consequences of crises, highlighting the need for gender mainstreaming, as well as the limits of its current application. Across these lessons, both continuations and the changes between the two crises highlight the centrality of gender to economic policy making, and the importance of understanding for developing comprehensive analysis.

As European Economic Governance moves into a new phase, complete with the spending capacities derived from the Recovery and Resilience facility, the importance of such feminist analysis has perhaps never been greater. While the oversight and recommendations of the European Semester were gender constitutive, in that they shaped the gendered regimes of economic and social policy, they were often limited in their impacts. Now with significant financial support available through a similar process, the gendered consequences will be significant. This means that the transformation imagined by the NextGenEU project will be a gendered transformation - but will it be one that reduces gender inequalities, or creates new ones and entrenches existing ones? The lessons outlined in this paper offer a starting point for answering this question.

\section{Correspondence:}

Muireann O'Dwyer

University of St Andrews

St Andrews, Scotland

email: mo71@st-andrews.ac.uk

\section{References}

Acker, J. (1990) 'Hierarchies, Jobs, Bodies: A Theory of Gendered Organizations'. Gender \& Society, Vol. 4, No. 2, pp. 139-58.

Addabbo, T., Klatzer, E., Schlager, C., Villa, P. and de Villota, P. (2018) 'Challenges of Austerity and Retrenchment of Gender Equality'. In O'Hagen, A. and Klatzer, E. (eds) Gender Budgeting in Europe (Cham: Springer), pp. 57-85.

Ahrens, P. (2018) Actors, Institutions, and the Making of EU Gender Equality Programs (London: Palgrave Macmillan). 
Allwood, G. (2017) 'Gender Mainstreaming and EU Climate Change Policy’. In MacRae, H. and Weiner, E. (eds) Towards Gendering Institutionalism: Equality in Europe (Maryland: Rowman \& Littlefield), pp. 43-61.

Allwood, G. (2020) 'Mainstreaming Gender and Climate Change to Achieve a Just Transition to a Climate-Neutral Europe'. Journal of Common Market Studies, Vol. 58, No. S1, pp. 173-86.

Bakker, I. (1994) The Strategic Silence: Gender and Economic Policy (London: Zed Books).

Bakker, I. (2003) 'Neo-liberal Governance and the Reprivatization of Social Reproduction: Social Provisioning and Shifting Gender Orders'. In Bakker, I. and Gill, S. (eds) Power, Production and Social Reproduction (London: Palgrave Macmillan), pp. 66-82.

Bakker, I. (2007) 'Social Reproduction and the Constitution of a Gendered Political Economy'. New Political Economy, Vol. 12, pp. 541-56.

Begg, I. (2020) 'The Eurogroup: No Longer “Jobs for the Boys"?' EUROPP. URL https://blogs. lse.ac.uk/europpblog/2020/07/08/the-eurogroup-no-longer-jobs-for-the-boys/ (accessed 6.30.21).

Bettio, F. (2013) The Impact of the Economic Crisis on the Situation of Women and Men and on Gender Equality Policies: Synthesis Report (Publications Office of the European Union).

Braun, B. (2016) 'Speaking to the People? Money, Trust, and Central Bank Legitimacy in the Age of Quantitative Easing'. Review of International Political Economy, Vol. 23, No. 6, pp. 1064-92.

Bruff, I. and Wöhl, S. (2016) 'Constitutionalizing Austerity, Disciplining the Household'. In Hozic, A.A. and True, J. (eds) Scandalous Economics: Gender and the Politics of Financial Crises (Oxford: Oxford University Press).

Buti, M. (2020) A Tale of Two Crises: Lessons from the Financial Crisis to Prevent the Great Fragmentation. VoxEU.org. URL https://voxeu.org/article/lessons-financial-crisis-preventgreat-fragmentation (accessed 2.16.21).

Buti, M. and Carnot, N. (2013) 'The Debate on Fiscal Policy in Europe: Beyond the Austerity Myth'. ECFIN Economic Brief, Vol. 20.

Çağlar, G. (2010) 'Multiple Meanings of Gender Budgeting: Gender Knowledge and Economic Knowledge in the World Bank and UNDP'. In Young, B. and Scherrer, C. (eds) Gender Knowledge and Knowledge Networks in International Political Economy (Nomos Verlagsgesellschaft), pp. 55-74.

Cappellini, B., Marilli, A. and Parsons, E. (2014) 'The Hidden Work of Coping: Gender and the Micro-politics of Household Consumption in Times of Austerity'. Journal of Marketing Management, Vol. 30, No. 15-16, pp. 1597-624.

Cavaghan, R. (2017) Making Gender Equality Happen: Knowledge, Change and Resistance in EU Gender Mainstreaming (New York: Routledge).

Cavaghan, R. and Elomäki, A. (2021) 'Dead Ends and Blind Spots in the European Semester: The Epistemological Foundation of the Crisis in Social Reproduction'. Journal of Common Market Studies. https://doi.org/10.1111/jcms.13288

Cavaghan, R. and O’Dwyer, M. (2018) 'European Economic Governance in 2017: A Recovery for Whom?' Journal of Common Market Studies, Vol. 56, No. S1, pp. 96-108.

Chieregato, E. (2021) 'Gender Equality and the EU's Economic Governance: The Strategic Use of Women's Employment Within Labor Market Reforms in Italy'. Social Politics: International Studies in Gender, State and Society, Vol. 28, No. 3, pp. 806-29. https://doi.org/10.1093/sp/jxaa012

Collignon, S. and Diessner, S. (2016) 'The ECB's Monetary Dialogue with the European Parliament: Efficiency and Accountability during the Euro Crisis?'. Journal of Common Market Studies, Vol. 54, No. 6, pp. 1296-312.

Cook, R. and Grimshaw, D. (2020) 'A Gendered Lens on COVID-19 Employment and Social Policies in Europe'. European Societies, Vol. 23, No. sup1, pp. S215-S227. https://doi.org/ $10.1080 / 14616696.2020 .1822538$ 
Copeland, P. and Daly, M. (2015) 'Social Europe: From “Add-on" to "Dependence-upon" Economic Integration'. In Social Policy and the Euro Crisis (Berlin: Springer), pp. 140-60.

Copeland, P. and Daly, M. (2018) 'The European Semester and EU Social Policy'. Journal of Common Market Studies, Vol. 56, No. 5, pp. 1001-18.

Crum, B. and Merlo, S. (2020) 'Democratic Legitimacy in the Post-crisis EMU'. Journal of European Integration, Vol. 42, No. 3, pp. 399-413.

Csehi, R., Schulz, D. (2022) 'The EU's New Economic Governance Framework and Budgetary Decision-Making in the Member States: Boon or Bane for Throughput Legitimacy?'. Journal of Common Market Studies, Vol. 60, No. 1, pp. 118-35.

Cullen, P. and Murphy, M.P. (2017) 'Gendered Mobilizations against Austerity in Ireland'. Gender, Work and Organization, Vol. 24, No. 1, pp. 83-97.

Cullen, P. and Murphy, M.P. (2021) 'Responses to the COVID-19 Crisis in Ireland: From Feminized to Feminist'. Gender, Work and Organization, Vol. 28, No. S2, pp. 348-65.

Daviter, F. (2007) 'Policy Framing in the European Union'. Journal of European Public Policy, Vol. 14, No. 4, pp. 654-66.

Dawson, M. (2018) 'New Governance and the Displacement of Social Europe: The Case of the European Semester'. European Constitutional Law Review, Vol. 14, pp. 191-209.

Dinan, D. (2016) 'Governance and Institutions: A More Political Commission'. Journal of Common Market Studies, Vol. 54, No. S1, p. 101-16.

EIGE (2021) 'Gender Equality and the Socio-economic Impact of the COVID-19 Pandemic'. European Institute for Gender Equality. https://eige.europa.eu/publications/gender-equalityand-socio-economic-impact-covid-19-pandemic (accessed 6.17.21).

Elomaki, A. (2012) 'The Price of Austerity: The Impact on Women's Rights and Gender Equality in Europe'. European Women's Lobby.

Elomäki, A. (2015) 'The Economic Case for Gender Equality in the European Union: Selling Gender Equality to Decision-Makers and Neoliberalism to Women's Organizations'. European Journal of Women's Studies, Vol. 22, No. 3, pp. 288-302.

Elomäki, A. (2019) 'Governing Austerity: Governance Reforms as Facilitators of Gendered Austerity in Finland'. Australian Feminist Studies, Vol. 34, No. 100, pp. 182-97.

Elomaki, A. and Kantola, J. (2021) 'Feminist Governance in the European Parliament: The Political Struggle over the Inclusion of Gender in the EU's Covid-19 Response'. Presented at 'Gender and Politics in Covid-19 Crisis: Including a Gender Perspective in Responses and Recovery’ Workshop. Online May 2021

Elson, D. (1991) 'Male bias in macro-economics: the case of structural adjustment'. In Elson, D. (ed.) Male Bias in the Development Process. (Manchester: Manchester University Press) pp. 164-90.

Elson, D. (1994) 'Micro, meso, macro: Gender and economic analysis in the context of policy reform'. In Bakker, I. (ed.) The Strategic Silence: Gender and Economic Policy. (Ottawa: Zed Books) pp. 33-45.

Elson, D. (1998) 'The economic, the political and the domestic: Businesses, states and households in the organisation of production'. New Political Economy, Vol. 3, No. 2, pp. 189-208.

Elson, D. (2004) 'Engendering government budgets in the context of globalization (s)'. International Feminist Journal of Politics, Vol. 6, No. 4, pp. 623-42.

Elson, D. (2010) 'Gender and the Global Economic Crisis in Developing Countries: A Framework for Analysis'. Gender and Development, Vol. 18, No. 2, pp. 201-12.

Elson, D. (2013) 'Economic Crises from the 1980s to the 2010s'. In Rai, S. and Waylen, G. (eds) New Frontiers in Feminist Political Economy (London: Routledge) pp. 189-212.

Elson, D. and Cagatay, N. (2000) 'The Social Content of Macroeconomic Policies'. World Development, Vol. 28, No. 7, pp. 1347-64.

Emejulu, A. and Bassel, L. (2017) 'Whose Crisis Counts? Minority Women, Austerity and Activism in France and Britain'. In Kantola, J. and Lombardo, E. (eds) Gender and the Economic Crisis in Europe (Berlin: Springer), pp. 185-208. 
Fabbrini, F. (2022) 'The Legal Architecture of the Economic Responses to COVID-19: EMU beyond the Pandemic'. Journal of Common Market Studies, Vol. 60, No. 1, pp. 186-203.

Follesdal, A. (2006) 'The Legitimacy Deficits of the European Union'. Journal of Political Philosophy, Vol. 14, No. 4, pp. 441-68.

Fourcade, M. (2006) 'The Construction of a Global Profession: The Transnationalization of Economics'. American Journal of Sociology, Vol. 112, No. 1, pp. 145-94.

Guerrina, R. (2017) 'Gendering European Economic Narratives: Assessing the Costs of the Crisis to Gender Equality'. In Kantola, J. and Lombardo, E. (eds) Gender and the Economic Crisis in Europe (Berlin: Springer), pp. 95-115.

Guerrina, R. (2020) 'From Amsterdam to Lisbon and Beyond: Reflections on Twenty Years of Gender Mainstreaming in the EU'. In Vanhercke, B., Ghailani, D., Spasova, S. and Pochet, P. (eds) Social Policy in the European Union 1999-2019: The Long and Winding Road (Brussels: ETUI), pp. 125-42.

Hubert, A. and Stratigaki, M. (2016) 'Twenty Years of EU Gender Mainstreaming: Rebirth out of the Ashes?' Femina Politica-Zeitschrift für feministische Politikwissenschaft, Vol. 25, No. 2, pp. 21-36.

Jacquot, S. (2015a) 'The Era of Gender Mainstreaming'. In Jacquot, S. (ed.) Transformations in EU Gender Equality (Basingstoke: Palgrave Macmillan), pp. 57-91.

Jacquot, S. (2015b) Transformations in EU Gender Equality: From Emergence to Dismantling (Basingstoke: Palgrave Macmillan).

Jacquot, S. (2020) 'Small Decisions? The European Commission and the Transformation of the Role of Legal Expert Groups: The Case of Gender Equality and Non-discrimination'. Journal of Common Market Studies, Vol. 58, No. 3, pp. 545-61.

Javorcik, B. (2021) How the Glass Ceiling Survived the Pandemic [WWW Document]. POLITICO. https://www.politico.eu/article/how-the-glass-ceiling-gender-inequality-survived-thecoronavirus-pandemic/ (accessed 6.29.21).

Jenichen, A., Joachim, J. and Schneiker, A. (2018) 'Explaining Variation in the Implementation of Global Norms: Gender Mainstreaming of Security in the OSCE and the EU'. International Political Science Review, Vol. 40, No. 5, pp. 613-26.

Jones, E. (2009) 'Output Legitimacy and the Global Financial Crisis: Perceptions Matter'. Journal of Common Market Studies, Vol. 47, No. 5, pp. 1085-105.

Jordan, J., Maccarrone, V. and Erne, R. (2020) 'Towards a Socialization of the EU's New Economic Governance Regime? EU Labour Policy Interventions in Germany, Ireland, Italy and Romania (2009-2019)'. British Journal of Industrial Relations, Vol. 59, No. 1, pp. 191-213.

Karamessini, M. and Rubery, J. (2013) Women and Austerity: The Economic Crisis and the Future for Gender Equality (Abingdon: Routledge).

Klatzer, E. and Rinaldi, A. (2020) '\#nextGenerationEU' Leaves Women Behind. (Greens/EFA Group in the European Parliament).

Ladi, S. and Tsarouhas, D.D. (2020) 'EU Economic Governance and Covid-19: Policy Learning and Windows of Opportunity'. Journal of European Integration, Vol. 42, No. 8, pp. 1041-56.

Laffan, B. (2014) 'Framing the Crisis, Defining the Problems: Decoding the Euro Area Crisis'. Perspectives on European Politics and Society, Vol. 15, No. 3, pp. 266-80.

Lokdam, H. (2020) 'We Serve the People of Europe': Reimagining the ECB's Political Master in the Wake of its Emergency Politics'. Journal of Common Market Studies, Vol. 58, No. 4, pp. 978-98.

Lombardo, E. and Meier, P. (2006) 'Gender Mainstreaming in the EU Incorporating a Feminist Reading?' European Journal of Women's Studies, Vol. 13, No. 2, pp. 151-66.

Lombardo, E. and Meier, P. (2008) 'Framing Gender Equality in the European Union Political Discourse'. Social Politics: International Studies in Gender, State and Society, Vol. 15, No. 1, pp. 101-29.

C 2021 The Authors. JCMS: Journal of Common Market Studies published by University Association for Contemporary European Studies and John Wiley \& Sons Ltd. 
Lombardo, E., Meier, P. and Verloo, M. (2009) The Discursive Politics of Gender Equality: Stretching, Bending and Policy-Making (Abingdon: Routledge).

Lord, C. and Magnette, P. (2004) 'E Pluribus Unum? Creative Disagreement about Legitimacy in the EU'. JCMS: Journal of Common Market Studies, Vol. 42, No. 1, pp. 183-202.

MacRae, H., Guerrina, R. and Masselot, A. (2021) 'A Crisis is a Terrible Thing to Waste: Feminist Reflections on the EU's Crisis Responses'. International Studies, Vol. 58, pp. 184-200.

McNamara, K.R. (2015a) 'JCMS Annual Review Lecture: Imagining Europe: The Cultural Foundations of EU Governance: JCMS Annual Review Lecture'. Journal of Common Market Studies, Vol. 53, pp. 22-39.

McNamara, K.R. (2015b) 'Building Culture: The Architecture and Geography of Governance in the European Union'. In Börner, S. and Eigmüller, M. (eds) European Integration, Processes of Change and the National Experience (Basingstoke: Palgrave Macmillan), pp. 100-18.

Miró, J. (2020) 'Austerity's Failures and Policy Learning: Mapping European Commission Officials' Beliefs on Fiscal Governance in the Post-crisis EU'. Review of International Political Economy, Vol. 28, No. 5, pp. 1224-48.

Montgomerie, J. (2016) 'Austerity and the Household: The Politics of Economic Storytelling'. British Politics, Vol. 11, No. 4, pp. 418-37.

Moschella, M., Pinto, L. and Diodati, N.M. (2020) 'Let's Speak More? How the ECB Responds to Public Contestation'. Journal of European Public Policy, Vol. 27, No. 3, pp. 400-18.

O’Dwyer, M. (2018) 'Making Sense of Austerity: The Gendered Ideas of European Economic Policy'. Comparative European Politics, Vol. 16, No. 5, pp. 745-61.

O’Dwyer, M. (2019) 'Expertise in European Economic Governance: A Feminist Analysis'. Journal of Contemporary European Research, Vol. 15, No. 2, pp. 162-78.

O’Dwyer, M. (2020) 'European Economic Governance: A Feminist Perspective'. In Bigo, D., Diez, T., Fanoulis, E., Rosamond, B. and Stivachtis, Y.A. (eds) The Routledge Handbook of Critical European Studies (Abingdon: Routledge) pp. 174-87.

Pansardi, P. and Battegazzorre, F. (2018) 'The Discursive Legitimation Strategies of the President of the Commission: A Qualitative Content Analysis of the State of the Union Addresses (SOTEU)'. Journal of European Integration, Vol. 40, No. 7, pp. 853-71.

Pollack, M.A. and Hafner-Burton, E. (2000) 'Mainstreaming Gender in the European Union'. Journal of European Public Policy, Vol. 7, No. 3, pp. 432-56.

Pottier, C. and Delette, G. (2019) 'Austerity as the Solution to the Eurozone Crisis: Analysing the Ordo-Liberal Pre-Eminence over Contending Framings of the Crisis'. Journal of Contemporary European Research, Vol. 15, No. 1, pp. 57-73.

Roberts, A. (2013) 'Financing Social Reproduction: The Gendered Relations of Debt and Mortgage Finance in Twenty-first-century America'. New Political Economy, Vol. 18, No. 1, pp. 21-42.

Rosamond, B. (2002) 'Imagining the European Economy: 'Competitiveness' and the Social Construction of 'Europe' as an Economic Space'. New Political Economy, Vol. 7, No. 2, pp. $157-77$.

Rosamond, B. (2014) 'Three Ways of Speaking Europe to the World: Markets, Peace, Cosmopolitan Duty and the EU's Normative Power'. British Journal of Politics \& International Relations, Vol. 16, No. 1, pp. 133-48.

Rubery, J. and Tavora, I. (2021) 'The Covid-19 Crisis and Gender Equality: Risks and Opportunities'. In Vanhercke, B., Spasova, S. and Fronteddu, B. (eds) Social Policy in the European Union: State of Play 2020: Facing the Pandemic (Brussels: ETUI), pp. 71-96.

Sanday, P.R. (1981) Female Power and Male Dominance: On the Origins of Sexual Inequality (Cambridge: Cambridge University Press)

Sassoon, A.S. (2018) Women and the State: The Shifting Boundaries of Public and Private (Abingdon: Routledge).

C 2021 The Authors. JCMS: Journal of Common Market Studies published by University Association for Contemporary European Studies and John Wiley \& Sons Ltd. 
Scharpf, F.W. (1997) 'Economic Integration, Democracy and the Welfare State'. Journal of European Public Policy, Vol. 4, No. 1, pp. 18-36.

Scharpf, F.W. (1999) Governing in Europe: Effective and Democratic? (Oxford: Oxford University Press).

Scharpf, F.W. (2014) 'Political Legitimacy and in a Non-Optimal Currency Area'. Cramme, O. \& Hobolt, S. (eds) Democratic Politics in a European Union under Stress (Oxford: Oxford University Press), pp. 19-47.

Schmidt, V.A. (2013) 'Democracy and Legitimacy in the European Union Revisited: Input, Output and 'Throughput'. Political Studies, Vol. 61, No. 1, pp. 2-22.

Schmidt, V.A. (2014) 'Speaking to the Markets or to the People? A Discursive Institutionalist Analysis of the EU's Sovereign Debt Crisis: Analysis of the EU's Sovereign Debt Crisis'. British Journal of Politics \& International Relations, Vol. 16, No. 1, pp. 188-209.

Schout, A., Wiersma, J.M., Neto, M.G. and Bokhorst, D. (2016) The Parliamentarisation of the EU's Economic Policy (The Hague: Clingendael, Netherlands Institute of International Relations).

Schuberth, H. and Young, B. (2011) 'The Role of Gender in Governance of the Financial Sector'. In Young, B., Bakker, I. and Elson, D. (eds) Questioning Financial Governance from a Feminist Perspective (Abingdon: Routledge), pp. 132-54.

Seikel, D. (2016) 'Flexible Austerity and Supranational Autonomy. The Reformed Excessive Deficit Procedure and the Asymmetry between Liberalization and Social Regulation in the EU'. JCMS: Journal of Common Market Studies, Vol. 54, No. 6, pp. 1398-416.

Shire, K.A. and Walby, S. (2020) 'Introduction: Advances in Theorizing Varieties of Gender Regimes'. Social Politics: International Studies in Gender, State and Society, Vol. 27, pp. 409-13.

Skjeie, H. (2006) “'Gender Equality”: On Travel Metaphors and Duties to Yield'. In Hellsten, S., Holli, A. and Daskalova, K. (eds) Women's Citizenship and Political Rights (Berlin: Springer), pp. 86-104.

Stevano, S., Mezzadri, A., Lombardozzi, L. and Bargawi, H. (2021) 'Hidden Abodes in Plain Sight: the Social Reproduction of Households and Labor in the COVID-19 Pandemic'. Feminist Economics, Vol. 27, Nos 1-2, pp. 271-87.

Strolovitch, D.Z. (2013) 'Of Mancessions and Hecoveries: Race, Gender, and the Political Construction of Economic Crises and Recoveries'. Perspectives on Politics, Vol. 11, No. 1, pp. 167-76.

Vanhercke, B., Verdun, A. (2022) 'The European Semester as Goldilocks: Macroeconomic Policy Coordination and the Recovery and Resilience Facility'. Journal of Common Market Studies, Vol. 60, No. 1, pp. 204-23.

Verdun, A. and Zeitlin, J. (2018) 'Introduction: The European Semester as a New Architecture of EU Socioeconomic Governance in Theory and Practice'. Journal of European Public Policy, Vol. 25, No. 2, pp. 137-48.

Verloo, M. and Lombardo, E. (2007) 'Contested Gender Equality and Policy Variety in Europe: Introducing a Critical Frame Analysis Approach'. In Verloo, M. (ed) Multiple Meanings of Gender Equality: A Critical Frame Analysis of Gender Policies in Europe (New York: Central European University Press), pp. 21-46.

Vesan, P., Corti, F. and Sabato, S. (2021) 'The European Commission's Entrepreneurship and the Social Dimension of the European Semester: From the European Pillar of Social Rights to the Covid-19 Pandemic'. Comparative European Politics, Vol. 19, pp. 277-95.

Vesan, P. and Pansardi, P. (2021) 'Speaking Social Europe: A Paradigmatic Shift in the European Commission Presidents' Social Policy Discourse?' Journal of European Social Policy Vol. 31, No. 4, pp. 365-79. 
Walby, S. (2020) 'Varieties of Gender Regimes'. Social Politics: International Studies in Gender, State and Society, Vol. 27, No. 3, pp. 414-31.

Woodward, A. (2004) 'Building Velvet Triangles: Gender and Informal Governance'. In Piattoni, S. and Christiansen, T. (eds) Informal Governance in the European Union (Cheltenham: Edward Elgar), pp. 76-93.

Woodward, A.E. (2012) 'From Equal Treatment to Gender Mainstreaming and Diversity Management'. In Abels, G. and Mushaben, J. (eds) Gendering the European Union (Basingstoke: Palgrave Macmillan), pp. 85-103.

Zeitlin, J. and Vanhercke, B. (2018) 'Socializing the European Semester: EU Social and Economic Policy Co-ordination in Crisis and Beyond'. Journal of European Public Policy, Vol. 25, No. 2, pp. 149-74. 